\title{
PENDEKATAN JAS DIPADU GI UNTUK MENINGKATKAN MOTIVASI BELAJAR SISWA
}

\section{THE JAS APPROACH WITH GI TO IMPROVE STUDENT'S LEARNING MOTIVATION}

\author{
Harjani Rini Riani ${ }^{1}$, Ika Priantari ${ }^{2}$, Ari Indriana Hapsari ${ }^{3}$ \\ Prodi Biologi FKIP Universitas Muhammadiyah Jember
}

Email : harjanirini02@gmail.com

\begin{abstract}
ABSTRAK
Penelitian ini bertujuan untuk mengetahui adanya peningkatan motivasi belajar siswa dengan menggunakan pendekatan Jelajah Alam Sekitar (JAS) dengan model pembelajaran Group Investigation (GI). Penelitian ini termasuk Penelitian Tindakan Kelas yang dilakukan dalam 2 siklus. Subyek dalam penelitian ini adalah siswa kelas X IPA 4 SMA Muhammadiyah 3 Jember dengan sampel penelitian berjumlah 34 orang. Intrumen yang digunakan yaitu lembar observasi, lembar wawancara dan angket motivasi. Hasil penelitian menunjukkan peningkatan rata-rata klasikal motivasi antara, siklus I dan siklus II. Pada siklus II rata-rata klasikal motivasi belajar siswa meningkat sebesar $15,2 \%$ dari $75,6 \%$ menjadi $90,8 \%$ dan telah mencapai kategori tinggi. Simpulan dari penelitian ini adalah pendekatan Jelajah Alam Sekitar (JAS) dengan model pembelajaran Group Investigation (GI) dapat meningkatkan motivasi belajar siswa.
\end{abstract}

Kata Kunci : Jelajah Alam Sekitar (JAS), Group Investigation (GI), Motivasi belajar

\begin{abstract}
This research aims to know the presence of increased student learning motivation using the Jelajah Alam Semesta (JAS) approach with a model of the Learning Group Investigation (GI) . This research includes class action Research conducted in 2 cycles. The subjects in this study are grade X Senior High School of Muhammadiyah 3 Jember with sample research amounted to 34 people. The instruments are used, namely sheets of observation, interview, and question form motivation. The results showed an increase between the cycle I and cycle II. On cycle II student learning of classical results increased by $15,2 \%$ of $75.6 \%$ to $90,8 \%$ and have reached the high category of success $50 \%$. A summary of this research is the Jelajah Alam Semesta (JAS) approach with a model of the Learning Group Investigation (GI) can improve of students learning motivation.
\end{abstract}

Keyword : Jelajah Alam Semesta (JAS), Group Investigation (GI), Learning motivation 
(p-ISSN 2527-7111; e-ISSN 2528-1615)

\section{PENDAHULUAN}

Perubahan mindset manusia abad 21 menuntut suatu perubahan yang sangat besar dalam pendidikan nasional. Merubah sistem pendidikan di Indonesia tidaklah mudah, namun perubahan ini merupakan sebuah keharusan agar tidak terlindas oleh perubahan jaman di era global (Wijaya, 2016). Sejalan dengan hal itu, Kemdikbud merumuskan bahwa paradigma pembelajaran abad 21 menekankan pada kemampuan siswa dalam mencari tahu dari berbagai sumber, kemampuan dalam merumuskan suatu permasalahan, mampu berpikir analitis, dan mampu bekerjasama atau berkolaborasi dalam menyelesaikan suatu permasalahan (Litbang Kemdikbud, 2013 dalam Wijaya, 2016). Hal yang paling penting dalam pendidikan abad 21 yakni mendorong siswa agar dapat memiliki suatu pengetahuan dan pemahaman yang mendalam supaya menjadi pembelajar sepanjang hayat (Wijaya, 2016).

Motivasi merupakan suatu dorongan dasar penggerak seseorang untuk bertingkah laku. Dorongan tersebut berasal dari dalam diri seseorang untuk melakukan sesuatu sesuai dengan dorongan yang ada dalam dirinya (Uno, 2012 dalam Setyaningsih, 2013). Motivasi merupakan salah satu faktor yang sangat penting dan menentukan dalam proses kegiatan mengajar. Keberhasilan pencapaian tujuan pembelajaran tergantung pada kemauan siswa dalam belajar, karena siswa tidak akan melakukan suatu aktivitas belajar apabila siswa tersebut tidak mempunyai motivasi belajar dalam dirinya (Setyaningsih, 2013).

Menurut Uno (2010, dalam Setyaningsih, 2013) motivasi seseorang dapat berasal dari dalam sendiri dan dapat juga berasal dari luar seseorang. Motivasi yang berasal dari dalam diri seseorang disebut juga dengan motivasi intrinsik, misalnya minat atau keingintahuan.Motivasi yang berasal dari luar seseorang disebut juga dengan motivasi ekstrinsik, misalnya keinginan untuk menerima suatu ganjaran atau menghindari hukuman.

Perlu diketahui juga bahwa motivasi berkaitan dengan suatu tujuan tertentu. Menurut Sardiman (2011, dalam Setyaningsih, 2013), terdapat 3 fungsi motivasi yakni, (1) motivasi berfungsi sebagai penggerak manusia dalam melakukan suatu kegiatan yang akan dikerjakan, (2) motivasi memberikan arah tujuan yang akan dicapai dan menyesuaikan dengan rumusan tujuan, dan (3) motivasi dapat menentukan perbuatan apa yang harus dikerjakan guna mencapai tujuan yang telah dirumuskan sebelumnya. 
Penerapan pendekatan Jelajah Alam Sekitar (JAS) dengan model pembelajaan Group Investigation (GI) merupakan salah satu pembelajaran yang memanfaatkan lingkungan sekitar dan terdapat kelompok investigasi dalam proses pengamatan. Proses investigasi dilakukan pada saat siswa melakukan pengamatan di alam sekitar dan mengidentifikasi masalah-masalah yang ada dengan cara berdiskusi dengan teman kelompok. Hasil pengamatan yang diperoleh siswa selanjutnya di analisis dan dipresentasikan di depan kelas (Rusman 2011, dalam Ostarika2014).

Penerapan pendekatan Jelajah Alam Sekitar (JAS) dengan model pembelajaan Group Investigation (GI) dapat mengajak siswa untuk mengeksplor diri secara langsung dengan alam atau lingkungan sekitar sehingga membuat proses pembelajaran lebih menyenangkan. Adanya kerjasama dengan kelompok pada pendekatan Jelajah Alam Sekitar (JAS) juga dapat menimbulkan minat siswa untuk belajar, meningkatkan kemandirian dan tanggung jawab siswa, serta menjadikan proses pembelajaran berlangsung lebih efektif. Proses pembelajaran yang menyenangkan dan efektif tersebut membuat siswa tidak merasa bosan dan dapat semangat untuk belajar (Marianti, 2016 dalam Azhar, 2015).

Hasil observasi yang dilakukan di kelas X IPA 4 yaitu motivasi belajar siswa yang rendah. Rendahnya motivasi belajar didapatkan dari hasil pengisian angket motivasi sebelum dilakukan tindakan (pra siklus). Data hasil pengisian angket menunjukkan bahwa motivasi belajar siswa rendah, hal ini dapat dilihat dari lebih dari $85 \%$ siswa dengan kriteria sedang dan rendah. Hal ini dapat terjadi karena adanya faktor ekstrinsik atau faktor luar yaitu lingkungan belajar kurang kondusif yang disebabkan karena beberapa siswa yang ramai saat pembelajaran berlangsung.

Hasil observasi juga menunjukkan bahwa di kelas X IPA 4 didapatkan rata-rata klasikal motivasi belajar siswa prasiklus yang di dapatkan dari pengisian angket motivasi belajar yaitu $54,5 \%$.

\section{METODE}

Jenis dari penelitian ini merupakan Penelitian Tindakan Kelas. Penelitian dilaksanakan dalam dua siklus, masing-masing siklus terdiri dari 4 tahap. Tahap pertama adalah perencanaan dengan membuat instrumen berupa angket motivasi belajar siswa tiap siklus yang terdiri atas 25 pernyataan, tahap kedua adalah pelaksanaan yaitu pada akhir pembelajaran tiap siklus siswa mengisi angket motivasi belajar yang telah 
disediakan oleh guru, tahap ketiga adalah observasi dengan mengamati perilaku siswa saat pembelajaran berlangsung, dan tahap keempat adalah refleksi yaitu menganalisis tindakan yang telah dilakukan mengenai hasil observasi kegiatan belajar mengajar. berikut langkah-langkah PTK:

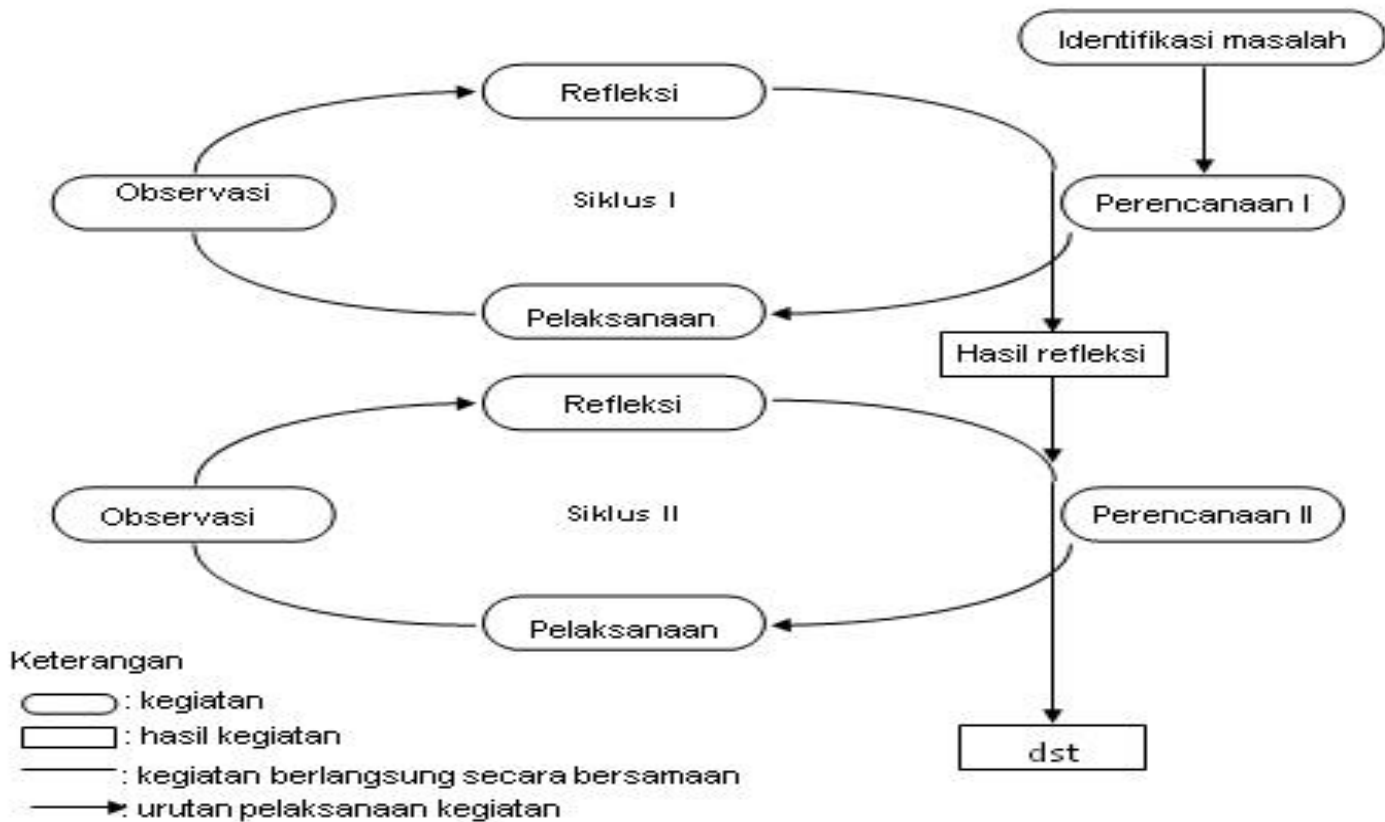

Gambar 1. Langkah-langkah PTK Model Spiral dari Kemmis dan Taggart

Subyek penelitian adalah siswa kelas X IPA 4 SMA Muhammadiyah 3 Jember Tahun ajaran 2016/2017 dengan alamat Jalan Mastrip No. 3 Jember, yang berjumlah 34 siswa. Penelitian ini menggunakan angket yang bertujuan untuk mengetahui motivasi belajar siswa secara klasikal. Kriteria kesuksesan dari penelitian ini dengan menggunakan rata-rata klasikal motivasi belajar jika telah mencapai $\geq 75$. Skor keseluruhan yang diperoleh berasal hasil angket motivasi yang diadakan di akhir tiap siklus.

Instrumen yang digunakan yaitu lembar observasi, lembar wawancara, dan angket motivasi. Angket motivasi diberikan di akhir tiap siklus yang terdiri atas 25 penyataan.

\section{HASIL DAN PEMBAHASAN}

Penelitian ini menerapkan dua siklus pembelajaran yang terdiri dari 3 kali pertemuan dalam satu siklus, dengan pendekatan dan model pembelajaran yang sama pada tiap siklusnya yaitu pendekatan Jelajah Alam Sekitar (JAS) dipadu dengan model 
(p-ISSN 2527-7111; e-ISSN 2528-1615)

pembelajaran Group Investigation (GI). Hasil motivasi belajar siswa per indikator pada siklus I pada mata pelajaran Biologi dengan materi pokok Pencemaran Lingkungan dapat dilihat pada tabel sebagai berikut.

Tabel 1. Hasil motivasi belajar biologi siswa pada siklus I

\begin{tabular}{lcccc}
\hline \multicolumn{1}{c}{ Indikator } & $\begin{array}{c}\text { Jumlah } \\
\text { Skor }\end{array}$ & $\begin{array}{c}\text { Skor } \\
\text { Ideal }\end{array}$ & $\begin{array}{c}\text { Persentase } \\
(\boldsymbol{\%})\end{array}$ & Kategori \\
\hline Hasrat dan keinginan berhasil & 460 & 660 & 69,7 & Sedang \\
\hline $\begin{array}{l}\text { Dorongan dan kebutuhan } \\
\text { dalam belajar }\end{array}$ & 465 & 660 & 70,5 & Sedang \\
\hline $\begin{array}{l}\text { Harapan dan cita-cita masa } \\
\text { depan }\end{array}$ & 285 & 396 & 73,9 & Tinggi \\
\hline $\begin{array}{l}\text { Penghargaan dalam belajar } \\
\text { Kegiatan yang menarik dalam } \\
\text { belajar }\end{array}$ & 390 & 528 & 73,9 & Tinggi \\
\hline $\begin{array}{l}\text { Lingkungan belajar yang } \\
\text { kondusif }\end{array}$ & 334 & 528 & 68,8 & Sedang \\
\hline
\end{tabular}

Keterangan:

$86 \%-100 \%$ : sangat tinggi

$71 \%-85 \% \quad$ : tinggi

$56 \%-70 \% \quad$ : sedang

$41 \%-55 \% \quad:$ rendah

$25 \%-40 \%$ : sangat rendah

Sumber: Arifin, 2011 dalam Yunikasari (2014)

Berdasarkan data di atas, hasil motivasi belajar siswa per indikator pada siklus I, Indikator hasrat dan keinginan dalam berhasil yaitu sebesar 69,7\% dengan kategori sedang, indikator dorongan dan kebutuhan belajar sebesar 70,5\% dengan kategori sedang. Indikator harapan dan cita-cita masa depan yaitu sebesar 73,9\% dengan kategori tinggi, indikator penghargaan dalam belajar sebesar 73,9\% dengan kategori tinggi. Indikator kegiatan yang menarik dalam belajar yaitu sebesar 68,8\% dengan kategori sedang, indikator lingkungan belajar yang kondusif sebesar 63,3\% dengan kategori sedang. Hasil motivasi belajar siswa perindikator masih tergolong dalam kategori sedang, hal ini dikarenakan guru belum bisa mengkondisikan kelas denga baik sehingga menyebabkan proses pembelajaran kurang kondusif dan siswa kurang bersemangat 
untuk belajar. Selain itu, siswa belum terbiasa mengikuti pembelajaran yang menggunakan pendekatan Jelajah Alam Sekitar (JAS) dengan model pembelajaran Group Investigation (GI) sehingga keinginan atau kemauan siswa dalam mengikuti pelajaran masih kurang.

Berdasarkan penelitian Yunikasari (2014), motivasi belajar siswa pada siklus I dengan indikator hasrat dan keinginan berhasil sebesar 78\% dengan kategori tinggi dan telah mencapai kriteria ketuntasan, indikator dorongan dan kebutuhan dalam belajar sebesar $71 \%$ dengan kategori tinggi namun belum mencapai kriteria ketuntasan, indikator harapan dan cita-cita masa depan sebesar $77 \%$ dengan kategori tinggi dan telah mencapai kriteria ketuntasan.

Indikator dorongan dan kebutuhan dalam belajar belum mencapai kriteria ketuntasan dikarenakan siswa masih belum berani dalam berbicara dan mengeluarkan pendapat serta menjawab pertanyaan. Hal tersebut disebabkan karena belum maksimalnya guru dalam memotivasi siswa dan pemberian kesempatan kepada siswa untuk aktif dalam mengeluarkan pendapat maupun saat menjawab pertanyaan.

Motivasi belajar siswa per indikator pada siklus II dapat dilihat pada tabel sebagai berikut.

Tabel 2. Hasil motivasi belajar siswa pada siklus II

\begin{tabular}{lcccc}
\hline \multicolumn{1}{c}{ Indikator } & $\begin{array}{c}\text { Jumlah } \\
\text { Skor }\end{array}$ & $\begin{array}{c}\text { Skor } \\
\text { Ideal }\end{array}$ & $\begin{array}{c}\text { Persentase } \\
(\%)\end{array}$ & Kategori \\
\hline Hasrat dan keinginan berhasil & 486 & 660 & 73,6 & Tinggi \\
\hline $\begin{array}{l}\text { Dorongan dan kebutuhan } \\
\text { dalam belajar }\end{array}$ & 486 & 660 & 73,6 & Tinggi \\
\hline $\begin{array}{l}\text { Harapan dan cita-cita masa } \\
\text { depan }\end{array}$ & 307 & 396 & 77,5 & Tinggi \\
\hline $\begin{array}{l}\text { Penghargaan dalam belajar } \\
\text { Kegiatan yang menarik dalam }\end{array}$ & 418 & 528 & 79,2 & Tinggi \\
\hline $\begin{array}{l}\text { belajar } \\
\text { Lingkungan belajar yang }\end{array}$ & 391 & 528 & 74,1 & Tinggi \\
kondusif & 364 & 528 & 68,9 & Sedang \\
\hline
\end{tabular}

Harjani Rini Riani et al., Pendekatan JAS ... 


\section{Keterangan:}

$86 \%-100 \%$ : sangat tinggi

$\mathbf{7 1 \% - 8 5 \%}$ : tinggi

$56 \%-70 \%$ : sedang

41\%-55\% : rendah

$25 \%-40 \%$ : sangat rendah

Sumber: Arifin, 2011 dalam Yunikasari (2014)

Hasil motivasi belajar siswa per indikator pada siklus II mengalami peningkatan. Persentase keberhasilan motivasi siswa pada siklus II yaitu indikator hasrat dan keinginan berhasil meningkat menjadi 73,6\% dengan kategori tinggi. Indikator dorongan dan kebutuhan dalam belajar meningkat menjadi 73,6\% dengan kategori tinggi. Indikator harapn dan cita-cita masa depan meningkat menajdi 77,5\% dengan kategori tinggi. Indikator penghargaan dalam belajar meningkat menjadi 79,2\% dengan kategori tingi. Indikator kegiatan yang menarik dalam belajar meningkat menjadi $74,1 \%$ dengan kategori tinggi, sedangkan pada indikator lingkungan belajar yang kondusif meningkat menjadi 68,9\% dengan kategori sedang.

Berdasarkan penelitian Yunikasari (2014), hasil motivasi belajar siswa pada siklus II pada indikator hasrat dan keinginan berhasil meningkat menjadi 83\% dengan kategori tinggi dan mencapai kriteria ketuntasan, indikator dorongan dan kebutuhan dalam belajar meningkat menjadi 785 dengan kategori tinggi dan telah mencapai kriteria ketuntasan, indikator harapan dan cita-cita masa depan meningkat menjadi $85 \%$ dengan kategori tinggi dan mencapai kriteria ketuntasan. Motivasi belajar siswa perindikator pada siklus II mengalami peningkatan dikarenakan guru telah memberikan motivasi kepada siswa dengan baik, siswa sudah berani dalam menyampaikan pendapat maupun saat menjawab pertanyaan, dan siswa lebih rajin dalam belajar yang disebabkan pembelajaran yang menyenangkan.

Peningkatan motivasi belajar siswa berdasarkan setiap indikator siklus I dan siklus II dapat dilihat pada Gambar 2 sebagai berikut. 


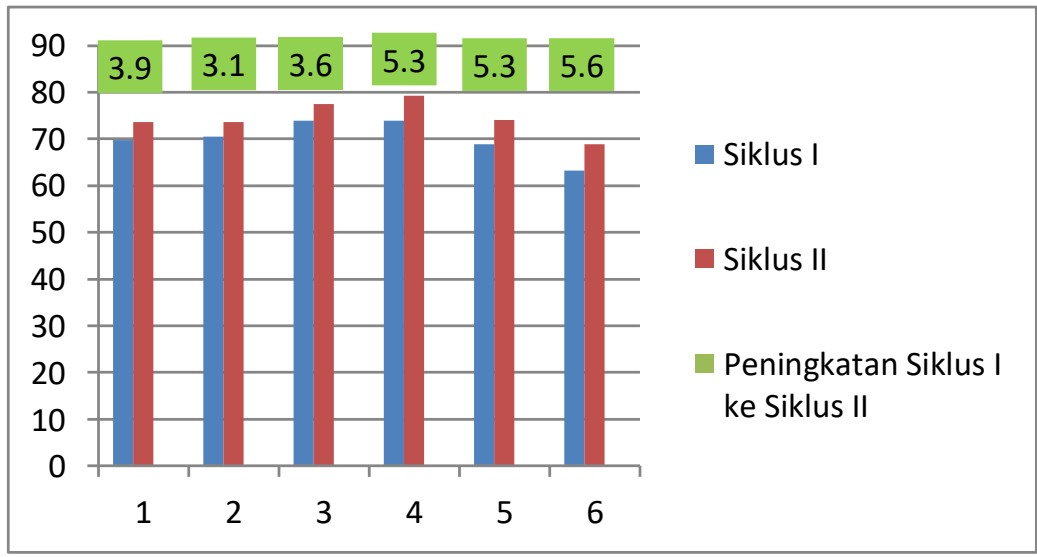

Gambar 2. Hasil motivasi belajar siswa siklus I dan sikus II

\section{Keterangan:}

1: indikator hasrat dan keinginan berhasil

2: indikator dorongan dan kebutuhan dalam belajar

3: indikator harapan dan cita-cita masa depan

4: indikator penghargaan dalm belajar

5: indikator kegiatan yang menarik dalam belajar

6: indikator lingkungan belajar yang kondusif

Indiikator 1 hingga indikator 5 pada siklus II mengalami peningkatan hingga kategori tinggi, namun pada indikator keenam hanya mengalami peningkatan hingga kategori sedang. Hal ini dikarenakan adanya motivasi negatif siswa yang dipengaruhi oleh faktor luar. Motivasi belajar yang berasal dari luar disebut juga dengan motivasi ekstrinsik. Faktor luar yang mempengaruhi motivasi siswa tersebut yaitu kondisi lingkungan belajar yang kurang kondusif, hal tersebut disebabkan karena terdapat beberapa siswa yang selalu menimbulkan keramaian dan kegaduhan di dalam kelas pada saat proses pembelajaran berlangsung. Proses pembelajaran yang kurang kondusif tersebut menyebabkan siswa kurang fokus dalam menerima materi pembelajaran.

Menurut Rifa'i dan Anni (2009, dalam Setyaningsih, 2013) ada beberapa faktor yang didukung oleh sejumlah teori psikologi dan penelitian terkait motivasi belajar siswa diantaranya ialah sikap, kebutuhan, rangsangan, afeksi, kompetensi, dan penguatan. Dari beberapa aspek motivasi yang telah dikemukakan oleh beberapa ahli, penyusunan indikator disesuaikan dengan aspek-aspek motivasi yang disampaikan oleh Uno dan Sardiman. Pengembangan aspek-aspek motivasi yang jadikan sebagai indikator dapat dilihat pada tabel berikut. 
Tabel 3. Aspek-aspek yang dijadikan sebagai indikator motivasi belajar

\begin{tabular}{|c|c|c|}
\hline \multirow{13}{*}{ Motivasi } & Aspek & Indikator \\
\hline & \multirow{2}{*}{ Sikap } & Keinginan mengikuti pelajaran IPA \\
\hline & & Kemauan mengerjakan soal-soal IPA \\
\hline & \multirow{2}{*}{ Kebutuhan } & Keingintahuan terhadap materi IPA \\
\hline & & Ketertarikan pada pelajaran IPA \\
\hline & \multirow{2}{*}{$\begin{array}{l}\text { Afeksi } \\
\text { (Perasaan) }\end{array}$} & Senang mengerjakan tugas IPA \\
\hline & & Manajemen belajar IPA \\
\hline & \multirow{2}{*}{ Rangsangan } & Adanya dorongan dari guru \\
\hline & & Lingkungan kelas yang kondusif \\
\hline & \multirow{2}{*}{ Kompetensi } & Ulet menghadapi kesulitan \\
\hline & & Senang mencari dan memecahkan masalah \\
\hline & \multirow{2}{*}{ Penguatan } & Dorongan siswa untuk berprestasi \\
\hline & & Cita-cita masa depan \\
\hline
\end{tabular}

Motivasi belajar siswa secara klasikal pada siklus I mengalami peningkatan pada siklus II. Peningkatan tersebut dapat dilihat pada tabel sebagai berikut.

Tabel 4. Hasil motivasi belajar siswa klasikal

\begin{tabular}{ccc}
\hline Siklus & $\begin{array}{c}\text { Jumlah Siswa yang } \\
\text { Mencapai Skor } \geq 64\end{array}$ & $\begin{array}{c}\text { Ketuntasan Klasikal } \\
\text { yang dicapai (\%) }\end{array}$ \\
\hline Siklus I & 9 & 27,2 \\
\hline Siklus II & 21 & 63,6 \\
\hline Peningkatan & 12 & 36,1 \\
\hline
\end{tabular}


Hasil motivasi belajar siswa secara klasikal dari siklus I hingga siklus II mengalami peningkatan. Jumlah siswa yang mengalami peningkatan sebanyak 12 siswa dari 9 siswa menjadi 21 siswa. Peningkatan yang terjadi dari siklus I hingga siklus II yaitu sebesar $36,1 \%$ dari $27,2 \%$ menjadi $63,6 \%$ dengan kategori tinggi dan telah mencapai kriteria keberhasilan.

Tabel 5. Hasil rata-rata klasikal motivasi belajar siswa

\begin{tabular}{cc}
\hline Siklus & Rata-rata Klasikal (\%) \\
\hline Siklus I & 75,6 \\
\hline Siklus II & 90,8 \\
\hline Peningkatan & 15,2 \\
\hline
\end{tabular}

Hasil rata-rata klasikal motivasi belajar siswa dari siklus I hingga siklus II mengalami peningkatan. Peningkatan yang terjadi dari siklus I hingga siklus II yaitu sebesar $15,2 \%$ dari $75,6 \%$ menjadi $90,8 \%$ telah mencapai kriteria keberhasilan yaitu rata-rata klasikal motivasi $\geq 75 \%$.

Penerapan pendekatan Jelajah Alam Sekitar (JAS) dengan model pembelajaran Group Investigation (GI) dapat meningkatkan motivasi belajar siswa dibandingkan sebelum menggunakan pendekatan Jelajah Alam Sekitar (JAS) dengan model pembelajaran Group Investigation (GI). Hal ini didukung oleh penelitian Widowati (2015), penerapan model pembelajaran dengan pendekatan Jelajah Alam Sekitar (JAS) merupakan salah satu bentuk motivasi ekstrinsik yang diberikan oleh peneliti untuk pencapaian hasil motivasi siswa pada materi ekosistem.

Berdasarkan penelitian Setyaningsih (2013), bahwa pembelajaran yang menggunakan model pembelajaran Group Investigation (GI) memberikan kebebasan kepada siswa untuk berpikir kritis dan melakukan investigasi topik dalam kelompok, serta siswa diberikan kebebasan dalam mengemukakan pendapat. Bagi siswa yang aktif akan diberikan reward berupa tepuk tangan atau tanda bintang oleh guru, sehingga siswa akan menjadi termotivasi dan senang dalam mengikuti pelajaran.

Hal ini serupa dengan penelitian Hendrawan (2015), yang mengemukakan bahwa penerapan model pembalajaran kooperatif tipe Group Investigation (GI) dapat 
membuat siswa lebih berani dalam mengeluarkan pendapat, menjawab maupun menyanggah pertanyaan, serta kondisi kelas yang menjadi lebih kondusif. Hal ini dikarenakan pada saat diskusi maupun presentasi kelompok guru memberikan penghargaan kepada siswa yang aktif sehingga hal tersebut mampu membangkitkan motivasi siswa dalam belajar. Hasil tersebut dapat memperkuat penelitian ini, bahwa pendekatan Jelajah Alam Sekitar (JAS) dipadu dengan model pembelajaran Group Investigation (GI) dapat meningkatkan motivasi belajar siswa karena pendekatan dan model pembelajaran tersebut dapat membuat proses pembelajaran lebih menyenangkan sehingga siswa lebih termotivasi dalam mengikuti proses pembelajaran.

\section{KESIMPULAN DAN SARAN}

Berdasarkan analisis dan pembahasan diatas, bahwa penerapan pendekatan Jelajah Alam Sekitar (JAS) dengan model pembelajaran Group Investigation (GI) dalam meningkatkan motivasi belajar siswa kelas X IPA 4 SMA Muhammadiyah 3 Jember pada pokok bahasan Perubahan Lingkungan. Penerapan pendekatan Jelajah Alam Sekitar (JAS) dengan model pembelajaran Group Investigation (GI) ditunjukkan oleh hasil rata-rata klasikal motivasi belajar siswa dari siklus I hingga siklus II mengalami peningkatan. Peningkatan yang terjadi dari siklus I hingga siklus II yaitu sebesar $15,2 \%$ dari $75,6 \%$ menjadi $90,8 \%$ telah mencapai kriteria keberhasilan yaitu rata-rata klasikal motivasi $\geq 75 \%$.

Saran yang dapat diberikan peneliti bagi guru bidang studi yaitu dapat menerapkan metode mengajar yang kreatif dan inovatif dengan menggunakan pendekatan dan model pembelajaran yang bervariasi. Bagi peneliti lain diharapkan dapat mengembangkan penelitian ini pada materi yang sesuai karena pendekatan Jelajah Alam Sekitar (JAS) hanya dapat diterapkan pada materi yang berhubungan dengan lingkungan.

\section{DAFTAR PUSTAKA}

Azhar, Khoirul. 2015. Peningkatan Hasil Belajar Dengan Pendekatan Jelajah Alam Sekitar Pada Materi Keanekaragaman Hayati Di MTs. Miftahul Huda Sarang Rembang Kelas VII Semester Genap. Skripsi tidak diterbitkan. Semarang: Universitas Islam Negeri Semarang. 
(p-ISSN 2527-7111; e-ISSN 2528-1615)

Hendrawan, I Nyoman Oka, dkk. 2015. Penerapan Model Pembelajaran Kooperatif Tipe Group Investigation (GI) Untuk Meningkatkan Motivasi Dan Hasil Belajar Ilmu Pengetahuan Sosial (IPS) Pada Siswa Kelas VIII B SMP Negeri 1 Nusa Penida Semester Genap Tahun Ajaran 2014/ 2015. Singaraja: Jurusan Pendidikan Sejarah Universitas Pendidikan Ganesha.

Ostarika, Ona. 2014. Penerapan Pendekatan Kooperatif Tipe Group Investigation Untuk Meningkatkan Aktivitas Dan Hasil Belajar Siswa. Skripsi tidak diterbitkan. Bengkulu: Universitas Bengkulu.

Setyaningsih, Romadoni. 2013. Penerapan Model Pembelajaran Group Investigation Untuk Meningkatkan Motivasi Dan Hasil Belajar Pesawat Sederhana Pada Siswa Kelas V Sekolah Dasar Negeri Selakambang Kabupaten Purbalingga. Skripsi tidak diterbitkan. Semarang: Universitas Negeri Semarang.

Widowati, Dyah Arum. 2015. Penerapan Metode Jelajah Alam Sekitar (JAS) Dalam Meningkatkan Motivasi Dan Hasil Belajar SiswaKelas VII E SMP Joannes Bosco Yogyakarta Pada Materi Ekosistem. Skripsi tidak diterbitkan. Yogyakarta: Universitas Sanata Dharma Yogyakarta.

Wijaya, Etistika Yuni.2016. Transformasi Pendidikan Abad 21 Sebagai Tuntutan Pengembangan Sumber Daya Manusia Di Era Gobal. Prosiding Seminar Nasional Pendidikan Matematika 2016: Universitas Negeri Malang.

Yunikasari, Dwi. 2014. Peningkatan Motivasi Belajar Matematika Melalui Model Pembelajaran Quantum Teaching Pada Siswa Kelas V SDN Sumberagung Jetis, Bantul. Skripsi tidak diterbitkan. Yogyakarta: Universitas Yogyakarta. 